\title{
The effect of press temperature on the total tocopherols, sterol, fatty acid, phenolic profile, in-vitro cytotoxicity assay, and anti-inflammatory activity
}

\author{
Hakan BASDOGAN $^{1}$ (D), Perihan Kübra AKMAN ${ }^{1}$ (D), Rusen Metin YILDIRIM $^{1}$ (D) , Osman SAGDIC ${ }^{1}$ (D), \\ Umit GECGEL ${ }^{2}$ (D), Zeynep Hazal TEKIN-CAKMAK ${ }^{1 *}$ (D), Salih KARASU ${ }^{1}$ (D)
}

\begin{abstract}
This study aimed to investigate the effect of press temperature on physicochemical properties, fatty acid, sterol, phenolic composition, in-vitro cytotoxicity assay, and anti-inflammatory activity of pumpkin seed oil. For this aim, the oils obtained at $100{ }^{\circ} \mathrm{C}$ (PSO2) and $150^{\circ} \mathrm{C}$ (PSO3) press temperature were compared with the cold press oil (PSO1). The application of press temperature at $150^{\circ} \mathrm{C}$ caused a significant decrease in the amount of sterol, while the press application at $100^{\circ} \mathrm{C}$ did not cause a significant change in the sterol composition. Total phenolic content, antioxidant capacity values, and individual phenolic content of PSO2 and PSO3 samples were significantly lower than those of PSO1. $30 \mathrm{mg} / \mathrm{mL}$ of PSO1, PSO2, and PSO3 samples exhibited a cytotoxic effect on the cells with an inhibition ratio of $75 \%, 48 \%$, and $39 \%$, respectively, indicating that press temperature reduced the cytotoxic effect of pumpkin seed oil. PSO1 showed anti-inflammatory activity ranged from $79 \%$ to $59 \%$, while at the same concentrations PSO2 and PSO3 exhibited approximately from $58 \%$ to $49 \%$. This study indicated that the bioactive properties of the cold press oil could be negatively affected by higher press temperature.
\end{abstract}

Keywords: cold-pressed oil; pumpkin seed oil; cytotoxic effect; anti-inflammatory activity; antioxidant activity.

Practical Application: Effect of press temperature on cold press extraction of pumpkin seed oil

\section{Introduction}

The pumpkin (Cucurbita sp.) is an annual plant that grows in the world's temperate and subtropical regions (Tadmor et al., 2005). It is regarded as a valuable dietary component especially due to its seed composition (Nawirska-Olszańska et al., 2013). Pumpkin seed has gained significant attention in recent years because of containing highly rich bioactive compounds with a variety of nutraceutical properties. With natural bioactive compounds, pumpkin seeds have a broad range of biological activity, as shown by in vivo experiments (Dyshlyuk et al., 2017). Since the main component of pumpkin seed is oil which constitutes $50 \%$ of the total content, the seeds are frequently utilized in the production of vegetable oil. In the last few years, several studies have specified the health effects of pumpkin seed oil against many diseases such as hypertension, diabetes, and cancer (Montesano et al., 2018).

The pumpkin seed oil has a high unsaturated fatty acid content of $73-80 \%$, mainly linoleic (36-61\%) and oleic acids (21-47\%) (Jurgita et al., 2007). This unsaturated fatty acid composition of the pumpkin seed oil enables it for improving the nutritional benefits of foods. The oil with a dark greenish color and strong nutty aroma is mainly used for salad dressing. The presence of phenolic compounds, tocopherols, and sterols is another beneficial property of pumpkin seeds (Parry et al., 2008). The phytochemicals in vegetables have been stated to possess strong antioxidant activity. There are too many studies that indicate the decreasing the risk of developing several pathologies such as cardiovascular diseases, cancer, and aging depending on the antioxidant activity in food matrixes (Hung et al., 2004; Wan et al., 2014).

In recent years, consumer trend has changed towards coldpressed oils worldwide, mainly due to increasing evidence that these oils have nutritional and health benefits (Neđeral et al., 2012). Since cold-pressed oils are produced without any chemical and heat application, their nutritional components and sensory properties are better preserved than refined oils. They are attributed as a kind of functional foods in terms of nutritional and sensory aspects as they contain essential fatty acids, natural antioxidants such as phenolic substances and tocopherols, and lipophilic bioactive components such as sterols (Akcicek \& Karasu, 2018; Tekin-Cakmak et al., 2021; Tekin \& Karasu, 2020). Although the "cold-pressed oil" means that not be performed any temperature application to the oil, the temperature increases spontaneously during the pressing process because of the friction and high operating pressures (Neđeral et al., 2012).

Both hot and cold press processes are used to obtain oil from pumpkin seeds. However in the traditional method, after forming a pulp with water and salt, the pulp is roasted for up to $60 \mathrm{~min}$ at $100-130^{\circ} \mathrm{C}$, which contributes to the protein fraction coagulation and causes the lipid fraction to be easily extracted by pressing (Raczyk et al., 2017). From this point of view, roasting the pumpkin seeds for producing the oil and as 
well as high pressing temperature in cold press processes affect the nutritional quality of the oil. Therefore, this study aimed to evaluate these changes depending on temperature treatment.

Some studies have reported on the effect of roasting processes on the changing of bioactive compounds of the pumpkin seed oil. Murkovic et al. (2004) applied $150{ }^{\circ} \mathrm{C}$ temperature on the pumpkin seeds and evaluated the changes of fatty acids and tocopherols, phytosterols, and secosisolariciresinol depending on the time. In the second part of this study, they investigated the changes of the volatile compound in the same condition (Siegmund \& Murkovic, 2004). Neđeral et al. (2012) produced the oil by roasted pumpkin seed paste (seed with water) at $110{ }^{\circ} \mathrm{C}$ for $45 \mathrm{~min}$, and compare the two types of cold-pressed oils. They also evaluated the effect of pressing temperature on the properties of oils. In another research, although the seeds were roasted at $110{ }^{\circ} \mathrm{C}$ for $40 \mathrm{~min}$, a cold-pressed procedure was used and investigate how it influenced the physicochemical properties of oils (Raczyk et al., 2017). Vujasinovic et al. (2012) also prepared a paste from seed, salt, and water and roasted the paste at $90^{\circ} \mathrm{C}, 110^{\circ} \mathrm{C}$, and $130^{\circ} \mathrm{C}$ for 30 and $60 \mathrm{~min}$ and evaluated the changes in biochemical composition of oils. These studies concentrated on fatty acid, tocopherol concentration, sterol content, and total phenolic compounds. Only Potočnik et al. (2018) studied the phenolic profile changes depending on temperature by roasting the paste from 90 to $200{ }^{\circ} \mathrm{C}$. Our study also investigated the phenolic profile of the hot and cold-pressed oil and enabled the evaluation of the changes of profile depending on the temperature. The novelty of our study is an investigation of in vitro cytotoxicity of cold-pressed and hot-pressed $\left(100{ }^{\circ} \mathrm{C}\right.$ and $150{ }^{\circ} \mathrm{C}$ ) seed oil toward Caco- 2 cells. Considering known the antioxidant properties of bioactive substances in pumpkin seed such as phenolic compound and tocopherol, it is essential to research the in-vitro cytotoxicity assay. Our main aim is to investigate the effect of temperature on phenolic profile, fatty acid, and tocopherol composition and sterol content and as well as in vitro cytotoxicity of the pumpkin seed oils.

\section{Materials and methods}

Firstly, pumpkin seed oil samples were produced by the cold-press extraction method. A cold press machine (Tokul Ltd, Co., İzmir, Turkey) was used for the production of oils. The cold press machine had a $10 \mathrm{~kg}$ kernel processing capacity per hour and the nozzle sizes of it were $5 \mathrm{~mm}$. The press temperature did not exceed $50{ }^{\circ} \mathrm{C}$ during the cold-press process. Then, in addition to cold press conditions, two press temperatures (100 and $150^{\circ} \mathrm{C}$ ) were applied for the hot press extraction of pumpkin seed oil. After pressing, filtration was applied to remove solid particles from oils. Finally, pumpkin seed oils were packaged with the colored bottles and waited at $4{ }^{\circ} \mathrm{C}$ for their analyses. All of the chemicals used in the analysis were obtained from Merck (Darmstadt, Germany) and Sigma (St. Louis, USA) with analytical purity and above (HPLC purity and GC purity).

\subsection{Physicochemical analysis of pumpkin seed and pumpkin seed oil}

The dry matter, protein, and oil content analysis of the pumpkin seed were performed according to the method described by official procedures. Dry matter contents analysis was carried out by drying at $105^{\circ} \mathrm{C}$ for $2.5 \mathrm{~h}$ in a drying oven (FN 120, Nuve, Ankara, Turkey). The total protein content was determined by the Dumas method by using an automatic nitrogen analyzer (FP 528 , Leco, USA). The total protein contents were determined by multiplying the obtained nitrogen values by 6.25 . The oil contents were determined by the Soxhlet extraction system, and hexane was used as a solvent (Karasu et al., 2015). The free fatty acidity (FFA) and peroxide values (PV) of the samples were determined according to the method described by IUPAC 2.201 and 2.501, respectively (International Union of Pure and Applied Chemistry, 1992). Total tocopherol content (mg of $\alpha$-tocopherol per kg of oil) of pumpkin seed oil was determined by the HPLC method of Association of Official Analytical Chemists (2000). The chromatographic separation was performed using the mobile phase consisted of ethyl acetate: acetic acid: hexane $(1: 1: 98 \mathrm{v} / \mathrm{v} / \mathrm{v})$ at a flow of $1.5 \mathrm{~mL} / \mathrm{min}$. Detection was carried out by the fluorescence detector at $290 \mathrm{~nm}$ (excitation) and 330 $\mathrm{nm}$ (emission) wavelengths. The number of tocopherols in the samples was expressed as ${ }^{\mu}$ g tocopherols in $\mathrm{mL}$ oil extract using external calibration curves $\left(0-10^{\mu} \mathrm{g} \mathrm{ml} \mathrm{r}^{2}>0.99\right)$, which were obtained with the a-tocopherol standard.

\subsection{Sterol composition determination}

Before sterol composition following pre-treatment was performed; sterol composition, $0.5 \mathrm{~g}$ of oil sample was transferred to a test tube and saponified with $5.0 \mathrm{~mL}$ saturated methanolic $\mathrm{KOH}$ at $80^{\circ} \mathrm{C}$ for one hour. Then, it was extracted with $5 \mathrm{~mL}$ of hexane three times; resulted solution was dried with anhydrous sodium sulfate. A $0.5 \mathrm{~mL}$ of dried hexane extract was silylated with solution of $0.1 \mathrm{~mL}$ bis (trimethylsilyl) trifluoroacetamide/ trimethylchlorosilane $(4: 1 v / v)$. After pre-treatment, the sterol composition of the oil samples was determined using GC equipped with FID. Separation of the sterols was conducted by using CP-SIL $24 \mathrm{CB}(60 \mathrm{~m} \times 0.32 \mathrm{~mm} \times 1.00 \mu \mathrm{m})$, and the following method parameters were identified for sterol composition analysis. Working conditions were as follows: carrier gas, helium; flow rate was $0.8 \mathrm{~mL} / \mathrm{min}$; injector temperature, $280{ }^{\circ} \mathrm{C}$; detector temperature, $300{ }^{\circ} \mathrm{C}$; oven temperature program, the initial temperature was $50{ }^{\circ} \mathrm{C}$ for $2 \mathrm{~min}$, increased at $60{ }^{\circ} \mathrm{C} / \mathrm{min}$ to $245^{\circ} \mathrm{C}$, held for $1 \mathrm{~min}$ and then increased at $3{ }^{\circ} \mathrm{C} / \mathrm{min}$ to 275 ${ }^{\circ} \mathrm{C}$, held for $35 \mathrm{~min}$ (Kamm et al., 2002).

\subsection{Fatty acid composition determination}

The wild plum and sour cherry kernel oil samples were methylated using BF3-methanol according to the method described by Association of Official Analytical Chemists (1990). The fatty acid methyl ester was transferred to gas chromatography (with a capillary column, HP-88, $100 \mathrm{~m} \times 0.25 \mathrm{~mm}$, film thickness: $0.20 \mathrm{~mm}$ ) and analyzed by gas chromatography (Agilent $6890 \mathrm{~N}$ ) equipped with a flame-ionization detector (FID). The carrier gas was selected as helium, with a flow rate of $0.5 \mathrm{~mL} / \mathrm{min}$. The temperatures of the injector and the detector were adjusted at 250 and $280{ }^{\circ} \mathrm{C}$, respectively. The initial oven temperature of $120^{\circ} \mathrm{C}$ was for $10 \mathrm{~min}$, raised to $240{ }^{\circ} \mathrm{C}$ at a rate of $5^{\circ} \mathrm{C} / \mathrm{min}$. The injection volume was $1 \mu \mathrm{L}$. The fatty acid methyl esters of wild plum and sour cherry kernel oil samples were identified 
by comparing the retention time of the samples and appropriate fatty acids methyl esters standards. The percentage of individual fatty acid content, saturated fatty acid (SFA), monounsaturated fatty acid (MUFA), and polyunsaturated fatty acid (PUFA) contents are presented.

\subsection{Extraction of phenolic compounds determination}

Methanol was used for the extraction of phenolic compounds from the wild plum and sour cherry kernel oil. Firstly, $2 \mathrm{~mL}$ hexane was mixed with $4 \mathrm{~mL}$ oil, and $4 \mathrm{~mL}$ of methanol was added to the hexane/oil mix. Then, the obtained solution was incubated at room temperature for $1 \mathrm{~h}$ in the shaking water bath (Memmert WB-22) for the extraction of the phenolic compounds. After the extraction process, the extracts were centrifuged (Hettich, Universal 320R, Tuttlingen, Germany) at 2,500 $\mathrm{g}$ for $10 \mathrm{~min}$ and the methanolic phase was taken. This operation was repeated three times to remove the hexane phase.

\subsection{Total phenolic content (TPC) determination}

TPC of pumpkin seed oil extracts was determined by the Folin-Ciocalteu colorimetric method (Singleton \& Rossi, 1965). Initialy, $2.5 \mathrm{~mL}$ of $0.2 \mathrm{~N}$ Folin-Ciocalteu reagent and $2 \mathrm{~mL}$ of $7.5 \%$ $\mathrm{Na}_{2} \mathrm{CO}_{3}$ were mixed respectively with $0.5 \mathrm{~mL}$ of the methanolic extract. This mixture was held for $45 \mathrm{~min}$ at room temperature in a dark place. At the end of the incubation time, the absorbance was recorded at $760 \mathrm{~nm}$ using a UV-vis spectrophotometer (Shimadzu, UV-1800). The TPC was determined as gallic acid equivalent. TPC was calculated from a calibration curve obtained with gallic acid. Total phenolic was expressed as Gallic acid equivalents (mg GAE/g extract).

\subsection{DPPH (2,2-diphenyl-1-picrylhydrazyl) radical scavenging activity determination}

The antioxidant capacity (AC) values of methanolic extracts were determined using DPPH (1,1-diphenyl-2- picrylhydrazyl) method according to the method described by Singh et al. (2002). After, $0.1 \mathrm{~mL}$ extract and $2 \mathrm{ml}$ methanolic DPPH solution were mixed. The mixture was vigorously shaken and incubated at room temperature for $30 \mathrm{~min}$. The absorbance was recorded at $517 \mathrm{~nm}$ by a spectrophotometer (UV-Mini 1240, Shimadzu, Kyoto, Japan). The Trolox equivalent's antioxidant capacity (TEAC) value is expressed as millimole Trolox equivalents per grams of cold press wild plum and sour cherry kernel oil sample (mmol TE/g of extract).

\subsection{Individual phenolic compounds determination}

Individual phenolic compounds of methanolic extracts were determined by HPLC coupled to a diode array (HPLCDAD, Shimadzu Corp., Kyoto, Japan). The methanolic extract was filtered through a $0.45-\mu \mathrm{m}$ membrane filter and $1 \mathrm{~mL}$ of the filtered sample was introduced to HPLC system (LC-20AD pump, SPDM20A DAD detector, SIL-20A HT autosampler, CTO10ASVP column oven, DGU-20A5R degasser, and CMB-20A communications bus module; (Shimadzu Corp., Kyoto, Japan). Separations were carried out at $40^{\circ} \mathrm{C}$ on a reversed-phase column
(Intersil $^{\oplus}$ ODS C-18, GL Sciences, Tokyo, Japan) with a $250 \mathrm{~mm}$ $\times 4.6 \mathrm{~mm}$ length, $5 \mu \mathrm{m}$ particle size. The mobile phases were solvent A (distilled water with $0.1 \%(v / v)$ acetic acid) and solvent B (acetonitrile with $0.1 \%(v / v)$ acetic acid). A gradient elution were $10 \% \mathrm{~B}$ ( 0 to $2 \mathrm{~min}$ ), $10 \%$ to $30 \% \mathrm{~B}$ (2 to $27 \mathrm{~min}$ ), $30 \%$ to $90 \% \mathrm{~B}(27$ to $50 \mathrm{~min}$ ) and $90 \%$ to $100 \% \mathrm{~B}$ (51 to $60 \mathrm{~min})$ and at $63 \mathrm{~min}$ returns to initial conditions. The flow rate was $1 \mathrm{~mL} / \mathrm{min}$. Chromatograms were taken at 254-356 nm. Identification and quantitative analysis were conducted based on retention times and standard curves. The result of individual phenolic amounts was expressed as $\mathrm{mg} / \mathrm{kg}$ for samples.

\subsection{In-vitro cytotoxicity assay}

In vitro cytotoxicity of PSO1 (cold-pressed), PSO2 (100 ${ }^{\circ} \mathrm{C}$ ), and $\mathrm{PSO} 3\left(150^{\circ} \mathrm{C}\right)$ was performed using the XTT assays as described by Cakır Koc et al. (2018) with some modifications. The Caco-2 adenocarcinoma cell line was used for the cytotoxic effects of samples. In brief, the cell line was incubated at $37^{\circ} \mathrm{C}$ for 3-4 days in a $5 \% \mathrm{CO}_{2}$ incubator. After incubation, the cells were removed by a trypsinization process and counted with a Thoma cell counting chamber. Then, $10^{4}$ cells/well are plated in the 96-well flat-bottom microplates and incubated at $37^{\circ} \mathrm{C}$ for $24 \mathrm{~h}$ to adhere to the bottom of the well. After incubation process, the different concentrations of the samples $(30 \mathrm{mg} / \mathrm{mL}$, $25 \mathrm{mg} / \mathrm{mL}, 20 \mathrm{mg} / \mathrm{mL}, 15 \mathrm{mg} / \mathrm{mL}, 10 \mathrm{mg} / \mathrm{mL}, 5 \mathrm{mg} / \mathrm{mL}, 2.5 \mathrm{mg} /$ $\mathrm{mL}$ and $1 \mathrm{mg} / \mathrm{mL}$ ) were added into the each well and incubated again for $24 \mathrm{~h}$. The part of the medium in the well was removed and $100 \mu \mathrm{L}$ of XTT solution was put in the well at $0.5 \mathrm{mg} / \mathrm{mL}$. Following the incubation of the microplates at $37{ }^{\circ} \mathrm{C}$ for 3 hours, optical density (OD) was measured at $450 \mathrm{~nm}$ using a microplate reader (Elisa reader Elx800, Biotek, Vermont, USA), and the number of viable cells was calculated according to the following equation (Equation 1):

Cell viability $(\%)=\left(\frac{O D_{\text {Sample }}}{O D_{\text {Control }}}\right) \times 100$

\subsection{Anti-inflammatory activity}

A protein denaturation assay described by Sakat et al. (2010) was performed to determine the anti-inflammatory activity of PSO samples. Briefly, a reaction mixture containing $25 \mu \mathrm{L}$ of pumpkin seed oil and $1 \%$ bovine serum albumin solution was prepared in $\mathrm{PBS}$, and $\mathrm{pH}$ was adjusted to 6.8. The reaction mixtures were held in a water bath at $37^{\circ} \mathrm{C}$ for 15 min, then incubated at $75^{\circ} \mathrm{C}$ for $5 \mathrm{~min}$. After cooling to room temperature, the absorbance of the samples was measured using a spectrophotometer (Shimadzu UV-1800, Kyoto, Japan) at 660 $\mathrm{nm}$. The assay was performed in triplicates and the percentage inhibition of BSA protein denaturation was calculated according to the Equation 2:

Percentinhibition $(\%)=\left(\frac{A_{c}-A_{S}}{A_{c}}\right) \times 100$

where $A_{C}$ is the absorbance of the control, and $A_{S}$ is the absorbance of the test sample. 


\subsection{Statistical analysis}

Statistical analysis results were reported as the mean values of the triplicates with their standard deviations. Tukey test was used for comparisons of the pumpkin seed oil samples obtained from four different drying methods. The statistical significance of the differences in the samples was determined by the one-way analysis of variance (ANOVA) using the JMP ver. 9 software (SAS Institute) at a significance level of 0.05.

\section{Result and discussion}

\subsection{Physicochemical properties}

The oil, protein, total carbohydrate, and dry matter content of the pumpkin seed were determined as $20.51 \%, 38.75 \%, 28.39 \%$, and $9.40 \%$ respectively. The PV value of the PSO1, PSO2, and PSO3 samples were $3.5,4.17$, and $5.32 \mathrm{mEq} \mathrm{O}_{2} / \mathrm{kg}$ respectively. FFA values of the samples were found to be $3.86,1.47$, and $1.34 \%$ for PSO1, PSO2, and PSO3 respectively. Similar results were also reported from Sarungallo et al. (2020). They reported that heating treatment before extraction of oil increased the FFA levels, but tend to decline with the increase of temperature and heating time. The minimum FFA level was reported from heat treatment at $120^{\circ} \mathrm{C}$ for 20 mins. In our study, the FFA content also decreased by increasing press temperature from $100{ }^{\circ} \mathrm{C}$ to $150^{\circ} \mathrm{C}$. The effects of different press temperatures on the FFA, PV, and induction period (IP) of the oils were found to be significant $(p<0.05)$. While the FFA decreased with the increase of press temperature, the value of PV increased significantly $(\mathrm{p}<0.05)$. The increase in the PV values of the samples can be explained by the increase in peroxide and second oxidation products and the decrease in antioxidant components. The total tocopherol content of the sample PSO1, PSO2, and PSO3 was found to be $414.14,596.01$, and $451.75 \mu \mathrm{g} / \mathrm{mL}$, respectively. The similar total tocopherol contents results of the pumpkin seed oil were reported as $589.4-1234 \mathrm{mg} / \mathrm{kg}$ by Stevenson et al. (2007) and 104.7-221.2 mg/kg by Benalia et al. (2015) study. A significant decrease was observed in the total tocopherol content as the press temperature increased. A loss of $13 \%$ and $37 \%$ was observed at $100^{\circ} \mathrm{C}$ and $150^{\circ} \mathrm{C}$, respectively, compared to cold press conditions. Sarungallo et al. (2020) also reported reduction in tocopherol content with the increasing heating temperature before the extraction process. The effect of heat treatment before extraction on tocopherol content was investigated by Bruscatto et al. (2019). They also reported a reduction in a-tocopherol content with increasing temperature. Tocopherol content is very important in determining the oxidative stability of oils. Our results show that the increase in temperature during pressing causes negative effects both in terms of health and in terms of decreasing the oxidative stability of the oil.

\subsection{Sterol and fatty acid compositions}

Sterols are bioactive components in vegetable oils that have various health effects, especially lowering blood cholesterol levels. The loss of sterols in pressing and subsequent processes leads to a decrease in the bioactive properties of the oil and health effects such as lowering serum cholesterol levels. Table 1 showed the effect of different press temperatures on the total sterol and sterol composition of pumpkin seed oils. The total sterol contents of the samples were determined as 2888, 2982, and $2650 \mathrm{mg} / \mathrm{kg}$ for PSO1, PSO2, and PSO3, respectively. The effect of the press temperature on the total sterol content was found to be significant $(\mathrm{p}<0.05)$. No significant difference was observed in terms of total sterol contents at press temperatures of $100{ }^{\circ} \mathrm{C}$ and $30^{\circ} \mathrm{C}$. The total sterol content obtained from the press temperature at $150{ }^{\circ} \mathrm{C}$ was significantly lower than that of the $100{ }^{\circ} \mathrm{C}$ and $30^{\circ} \mathrm{C}$. Significant loss of sterol content was observed when the press temperature was increased to $150^{\circ} \mathrm{C}$.

Table 1. Total sterol amount and individual sterol compositions of PSO samples.

\begin{tabular}{|c|c|c|c|}
\hline Sterols (\%) & PSO1 & $\mathrm{PSO} 2$ & PSO3 \\
\hline B-Sitosterol+Spinasterol & $48.69 \pm 0.229^{a}$ & $47.77 \pm 0.224^{\mathrm{b}}$ & $46.56 \pm 0.221^{c}$ \\
\hline Brassicasterol & nd & $0.08 \pm 0.004$ & nd \\
\hline$\Delta^{5-23}$ Stigmastadienol & nd & nd & nd \\
\hline$\Delta^{5-24}$ Stigmastadienol & $22.77 \pm 0.414^{\mathrm{a}}$ & $22.18 \pm 0.351^{\mathrm{a}}$ & $22.45 \pm 0.38^{\mathrm{a}}$ \\
\hline$\Delta^{5}$ Avenasterol & $0.34 \pm 0.009^{\mathrm{a}}$ & $0.29 \pm 0.006^{\mathrm{b}}$ & $0.22 \pm 0.008^{c}$ \\
\hline$\Delta^{7}$ - Campesterol & $5.86 \pm 0.636^{\mathrm{a}}$ & $4.43 \pm 0.578^{\mathrm{a}}$ & $3.02 \pm 0.619^{b}$ \\
\hline$\Delta^{7}$ Avenasterol & $21.38 \pm 5.975^{\mathrm{a}}$ & $20.06 \pm 6.489^{c}$ & $19.91 \pm 6.44^{\mathrm{b}}$ \\
\hline$\Delta^{7}$ Stigmastenol & $4.81 \pm 0.19^{\mathrm{a}}$ & $3.82 \pm 0.150^{b}$ & $3.91 \pm 0.195^{\mathrm{b}}$ \\
\hline Eritrodiol + Uvaol & nd & nd & nd \\
\hline Campestanol & $0.08 \pm 0.047^{c}$ & $0.11 \pm 0.065^{\mathrm{b}}$ & $0.15 \pm 0.08^{\mathrm{a}}$ \\
\hline Campesterol & $0.74 \pm 0.04^{\mathrm{a}}$ & $0.67 \pm 0.037^{\mathrm{b}}$ & $0.62 \pm 0.039^{c}$ \\
\hline Clerosterol & $0.37 \pm 0.046^{\mathrm{a}}$ & $0.034 \pm 0.043^{\mathrm{b}}$ & $0.37 \pm 0.045^{\mathrm{a}}$ \\
\hline Sitostanol & $1.10 \pm 0.425^{\mathrm{a}}$ & $0.73 \pm 0.282^{\mathrm{b}}$ & $0.24 \pm 0.09^{c}$ \\
\hline Stigmasterol & $0.29 \pm 0.031^{\mathrm{a}}$ & $0.12 \pm 0.012^{c}$ & $0.13 \pm 0.014^{\mathrm{b}}$ \\
\hline$\Delta^{7-9-11}$ Stigmastatrienol & $0.236 \pm 0.021^{\mathrm{b}}$ & $0.300 \pm 0.177^{\mathrm{a}}$ & $0.301 \pm 0.177^{\mathrm{a}}$ \\
\hline 24-methylen-cholesterol & $0.06 \pm 0.001^{\mathrm{b}}$ & $0.07 \pm 0.022^{\mathrm{a}}$ & $0.07 \pm 0.022^{\mathrm{a}}$ \\
\hline Total Sterol & $2888 \pm 38.521^{b}$ & $2982 \pm 40.817^{a}$ & $2667 \pm 67.125^{c}$ \\
\hline
\end{tabular}

Different lowercase letter in the same line indicates differences between samples subjected to different drying methods (P<0.05); PSO: pumpkin seed oil; PSO1: cold-pressed PSO; PSO2: hot-pressed PSO at $100^{\circ} \mathrm{C}$; PSO3: hot-pressed PSO at $150^{\circ} \mathrm{C}$. nd: not detected 
Sterols are bioactive components sensitive to oxidation. The significant loss in total sterol content can be explained by the increase in the oxidation rate of sterols with the effect of heat treatment and the transformation of sterols into their oxidation products (Lin et al., 2017).

In a study, the formation of oxidation products of sterols was observed at 150,180 , and $210^{\circ} \mathrm{C}$. A significant increase was observed in sterol oxidation products at each temperature and the concentration of sterol oxidation products increased with the temperature increase (Lin et al., 2017). The increase in sterol oxidation products and sterol loss by the thermal treatments above $100^{\circ} \mathrm{C}$ was reported from different studies (Barriuso et al., 2015; Chen et al., 2020; González-Larena et al., 2011; Kemmo et al., 2008). It was reported that sterol oxidation products had cytotoxic effects and the rate of their formation increased by thermal treatment (Lin et al., 2017; O'Callaghan et al., 2014). The results of this study indicated that the press temperature at $150{ }^{\circ} \mathrm{C}$ would not meet the health effects expected from coldpressed oils in terms of sterol contents.

$\beta$-Sitosterol+spinasterol, $\Delta^{7,25}$ Stigmastadienol and $\Delta^{7}$ Avenasterol were identified as the major sterols. Spinasterol $+\beta$-sitosterol and $\Delta^{7,25}$ stigmastadienol were also reported as most abundant sterols by Ogrodowska et al. (2017). Similar sterol composition results were also reported from Rabrenovic et al. (2016) and Rabrenović et al. (2014) study. The effect of press temperature on the sterol composition of the samples varied according to the type of sterol. While the effect of press temperature on $\Delta^{5-24}$ Stigmastadienol of the samples was found to be insignificant, the effect of press temperature on $\beta$-Sitosterol+spinasterol, $\Delta^{7}$ Campesterol, and $\Delta^{7}$ Avenasterol was found to be significant.

The effect of press temperature on fatty acid composition was shown in Table 2. The effect of press temperature was found to be significant $(p<0.05)$. Linoleic, oleic, and palmitic acid were the major fatty acids in all samples. Similar results were reported from previously published studies (Akin et al., 2018; Begić et al., 2020). As the press temperature increased, the linoleic acid content increased and the oleic acid content decreased. The effect of temperature on total saturated fatty acid was insignificant $(\mathrm{p}>0.05)$. No evidence of trans fatty acid was obtained in any oil sample. These results showed that the high press temperature did not have a significant effect on the fatty acid composition and did not cause the formation of trans fatty acids.

\subsection{Total phenolic content, antioxidant activity, and individual phenolic composition}

Table 3 showed the effect of different press temperatures on the TPC, phenolic profile, and antioxidant capacity values of the pumpkin seed oil samples. TPC values of the samples were determined as $584.07,298.5$, and $373.23 \mathrm{mg} / \mathrm{L}$ for PSO1, PSO2, and PSO3, respectively. According to Table 3, the applied press temperature significantly decreased the TPC and DPPH value of the samples $(p<0.05)$. The TPC decreased approximately two times more than the control samples (PSO1) compared to the samples (PSO2) obtained by application of $100^{\circ} \mathrm{C}$ press temperature. The dramatic decrease in TPC by applying heat treatment could be explained by the degradation of phenolic compounds due to high-temperature press conditions. The phenolic content of vegetable oils has an important contribution to oxidative stability, sensory properties, antioxidant, antimicrobial, and anti-carcinogenic properties. The degradation of the phenolic compounds in the oil with the application of heat treatment led to a decrease in these bioactive properties of oils. The change in the DPPH value by applying heat treatment is similar to TPC. With the heat treatment, the antioxidant capacity value of the samples significantly decreased $(\mathrm{p}<0.05)$.

Table 3 shows the distribution of individual phenolic compounds in addition to TPC. 14 different phenolic compounds were identified in pumpkin seed oils. Phenolic acids namely, trans-cinnamic acid, syringic acid, p-coumaric acid, and vanillic acids were respectively determined as the most abundant phenolic compounds. Other phenolic acids such as protocatechuic acid and caffeic acid and flavonoids namely catechin and kaempferol were determined as higher than $1 \mathrm{mg} / \mathrm{kg}$. The amount and distribution of the phenolic acids were similar to the study reported by Akin et al. (2018). In their study, syringic acid and ferulic acid were determined as major phenolic acid and their content was similar to our study. Trans-cinnamic acid was not reported in their study. Potočnik et al. (2018) identified trans-cinnamic, vanillic, p-coumaric, and caffeic acid in pumpkin seed oil. As can be seen from the table, a significant decrease in the amounts of most of the phenolic compounds was observed with the increase of press temperature. The amount of trans-cinnamic acid, syringic acid, and ferulic acid decreased by $60 \%, 46 \%$, and $42 \%$ respectively as the temperature increased to $150^{\circ} \mathrm{C}$. Epigallocatechin, on the other hand, could not be detected in the PSO2 sample with heat application at $100^{\circ} \mathrm{C}$, indicating that applied heat treatment caused complete degradation in epigallocatechin. These results

Table 2. Fatty acid composition of PSO samples.

\begin{tabular}{|c|c|c|c|}
\hline Fatty acid (\%) & PSO1 & PSO2 & PSO3 \\
\hline $\mathrm{C}_{8: 0}$ & nd & nd & nd \\
\hline $\mathrm{C}_{10: 0}$ & nd & nd & nd \\
\hline $\mathrm{C}_{12: 0}$ & nd & nd & nd \\
\hline $\mathrm{C}_{14: 0}$ & $0.052 \pm 0.007^{\mathrm{a}}$ & $0.048 \pm 0.002^{\mathrm{b}}$ & $0.045 \pm 0.001^{\mathrm{b}}$ \\
\hline $\mathrm{C}_{14: 1}$ & nd & nd & nd \\
\hline $\mathrm{C}_{16: 0}$ & $11.01 \pm 0.10^{\mathrm{b}}$ & $11.56 \pm 0.11^{\mathrm{a}}$ & $11.54 \pm 0.02^{\mathrm{a}}$ \\
\hline $\mathrm{C}_{16: 1}$ & $0.15 \pm 0.01^{\mathrm{a}}$ & $0.12 \pm 0.01^{\mathrm{a}}$ & $0.13 \pm 0.01^{\mathrm{a}}$ \\
\hline $\mathrm{C}_{18: 0}$ & $5.64 \pm 0.04^{\mathrm{a}}$ & $5.04 \pm 0.02^{\mathrm{b}}$ & $5.01 \pm 0.13^{\mathrm{b}}$ \\
\hline $\mathrm{C}_{18: 1}$ & $31.82 \pm 0.19^{\mathrm{a}}$ & $29.16 \pm 0.11^{\mathrm{b}}$ & $29.30 \pm 0.21^{\mathrm{b}}$ \\
\hline $\mathrm{C}_{18: 2}$ & $50.54 \pm 0.21^{\mathrm{b}}$ & $53.48 \pm 0.33^{\mathrm{a}}$ & $53.38 \pm 0.26^{a}$ \\
\hline $\mathrm{C}_{18: 3}$ & $0.45 \pm 0.01^{\mathrm{a}}$ & $0.29 \pm 0.02^{\mathrm{b}}$ & $0.13 \pm 0.02^{c}$ \\
\hline $\mathrm{C}_{20: 0}$ & $0.18 \pm 0.02^{\mathrm{a}}$ & $0.13 \pm 0.01^{\mathrm{b}}$ & $0.11 \pm 0.00^{c}$ \\
\hline $\mathrm{C}_{20: 1}$ & $0.09 \pm 0.00^{\mathrm{b}}$ & $0.09 \pm 0.00^{\mathrm{b}}$ & $0.11 \pm 0.00^{c}$ \\
\hline $\mathrm{C}_{22: 0}$ & $0.11 \pm 0.00^{\mathrm{b}}$ & $0.92 \pm 0.01^{\mathrm{a}}$ & $0.90 \pm 0.07^{\mathrm{a}}$ \\
\hline $\mathrm{C}_{22: 1}$ & nd & nd & nd \\
\hline$\Sigma_{\mathrm{SFA}}$ & $16.99 \pm 0.07^{\mathrm{b}}$ & $17.69 \pm 0.16^{\mathrm{a}}$ & $17.60 \pm 0.02^{\mathrm{a}}$ \\
\hline$\Sigma_{\mathrm{UFA}}$ & $83.01 \pm 0.03^{\mathrm{a}}$ & $82.31 \pm 0.48^{\mathrm{b}}$ & $82.39 \pm 0.52^{\mathrm{b}}$ \\
\hline$\Sigma_{\mathrm{PFA}}$ & $50.99 \pm 0.22^{\mathrm{b}}$ & $53.77 \pm 0.36^{\mathrm{a}}$ & $53.11 \pm 0.29^{\mathrm{a}}$ \\
\hline Total Trans & nd & nd & nd \\
\hline
\end{tabular}


Table 3. TPC, DPPH, and individual phenolic compositions of PSO samples.

\begin{tabular}{lccc}
\hline \multicolumn{1}{c}{ Phenolic Compounds } & PSO1 & PSO2 & PSO3 \\
\cline { 2 - 4 } & & $\mathbf{~ m g} / \mathbf{k g}$ & $2.295 \pm 0.09^{\mathrm{b}}$ \\
3,4 Dimethoxy Benzaldehyde & $2.765 \pm 0.09^{\mathrm{a}}$ & $2.225 \pm 0.10^{\mathrm{b}}$ & $1.650 \pm 0.14^{\mathrm{b}}$ \\
4-OH Benzoic Acid & $6.175 \pm 0.14^{\mathrm{a}}$ & $2.752 \pm 0.21^{\mathrm{b}}$ & $2.045 \pm 0.06^{\mathrm{b}}$ \\
Caffeic Acid & $2.675 \pm 0.02^{\mathrm{a}}$ & $1.570 \pm 0.07^{\mathrm{c}}$ & $3.055 \pm 0.01^{\mathrm{b}}$ \\
Catechin & $3.230 \pm 0.04^{\mathrm{a}}$ & $3.325 \pm 0.45^{\mathrm{a}}$ & $0.537 \pm 0.03^{\mathrm{c}}$ \\
Ellagic Acid & $0.832 \pm 0.04^{\mathrm{a}}$ & $0.725 \pm 0.03^{\mathrm{b}}$ & $0.305 \pm 0.01^{\mathrm{b}}$ \\
Epigallocatechin & $1.013 \pm 0.02^{\mathrm{a}}$ & $\mathrm{nd}$ & $5.025 \pm 0.03^{\mathrm{b}}$ \\
Ferrulic Acid & $8.583 \pm 0.25^{\mathrm{a}}$ & $1.597 \pm 0.13^{\mathrm{c}}$ \\
Kaempferol & $3.297 \pm 0.56^{\mathrm{a}}$ & $5.310 \pm 0.35^{\mathrm{b}}$ & $1.131 \pm 0.04^{\mathrm{b}}$ \\
Luteolin & $1.381 \pm 0.26^{\mathrm{a}}$ & $2.432 \pm 0.09^{\mathrm{b}}$ & $4.006 \pm 0.01^{\mathrm{c}}$ \\
p-Coumaric Acid & $4.906 \pm 0.15^{\mathrm{a}}$ & $1.182 \pm 0.25^{\mathrm{b}}$ & $1.382 \pm 0.03^{\mathrm{b}}$ \\
Protocatechuic Acid & $2.282 \pm 0.11^{\mathrm{a}}$ & $4.375 \pm 0.24^{\mathrm{b}}$ & $4.737 \pm 0.32^{\mathrm{c}}$ \\
Syringic Acid & $8.732 \pm 0.35^{\mathrm{a}}$ & $0.925 \pm 0.17^{\mathrm{c}}$ & $4.56 \pm 0.09^{\mathrm{c}}$ \\
Trans-cinnamic Acid & $11.667 \pm 0.45^{\mathrm{a}}$ & $5.79 \pm 0.35^{\mathrm{b}}$ & $2.915 \pm 0.09^{\mathrm{b}}$ \\
Vanilic Acid & $4.840 \pm 0.19^{\mathrm{a}}$ & $7.978 \pm 0.67^{\mathrm{b}}$ & $373.23 \pm 5.98^{\mathrm{b}}$ \\
TPC (mg GAE/g extract) & $584.07 \pm 8.37^{\mathrm{a}}$ & $3.042 \pm 0.11^{\mathrm{b}}$ & $14.74 \pm 0.55^{\mathrm{b}}$ \\
DPPH (mmol TE/g of extract) & $28.55 \pm 1.05^{\mathrm{a}}$ & $298.50 \pm 5.94^{\mathrm{c}}$ & $16.82 \pm 0.75^{\mathrm{b}}$ \\
\hline
\end{tabular}

Different lowercase letter in the same line indicates differences between samples subjected to different drying methods (P<0.05); PSO: pumpkin seed oil; PSO1: cold-pressed PSO; PSO2: hot-pressed at $100{ }^{\circ} \mathrm{C}$; PSO3: hot-pressed at $150^{\circ} \mathrm{C}$; TPC: Total phenolic content, DPPH: 1,1-diphenyl-2- picrylhydrazyl antioxidant method; nd: not detected.

Table 4. Cytotoxic effect of PSO samples on Caco-2 adenocarcinoma cells.

\begin{tabular}{cccc}
\hline \multirow{2}{*}{ Sample amount } & \multicolumn{3}{c}{ Caco-2 cell viability (\%) } \\
\cline { 2 - 4 } & PSO-1 & PSO-2 & PSO-3 \\
\hline $30 \mathrm{mg} / \mathrm{mL}$ & $25.01 \pm 0.93^{\mathrm{c}}$ & $52.76 \pm 3.72^{\mathrm{b}}$ & $61.71 \pm 1.10^{\mathrm{a}}$ \\
$25 \mathrm{mg} / \mathrm{mL}$ & $25.64 \pm 1.03^{\mathrm{c}}$ & $58.86 \pm 4.35^{\mathrm{b}}$ & $66.57 \pm 5.59^{\mathrm{a}}$ \\
$20 \mathrm{mg} / \mathrm{mL}$ & $29.40 \pm 0.39^{\mathrm{c}}$ & $68.32 \pm 0.99^{\mathrm{b}}$ & $84.90 \pm 1.23^{\mathrm{a}}$ \\
$15 \mathrm{mg} / \mathrm{mL}$ & $32.25 \pm 0.20^{\mathrm{c}}$ & $81.86 \pm 3.45^{\mathrm{b}}$ & $94.15 \pm 0.45^{\mathrm{a}}$ \\
$10 \mathrm{mg} / \mathrm{mL}$ & $46.89 \pm 1.53^{\mathrm{c}}$ & $89.26 \pm 4.52^{\mathrm{b}}$ & $97.06 \pm 0.62^{\mathrm{a}}$ \\
$5 \mathrm{mg} / \mathrm{mL}$ & $63.54 \pm 5.50^{\mathrm{c}}$ & $96.54 \pm 0.82^{\mathrm{b}}$ & $99.37 \pm 0.28^{\mathrm{a}}$ \\
$2.5 \mathrm{mg} / \mathrm{mL}$ & $70.78 \pm 2.04^{\mathrm{b}}$ & $99.59 \pm 0.26^{\mathrm{a}}$ & $99.46 \pm 0.95^{\mathrm{a}}$ \\
$1 \mathrm{mg} / \mathrm{mL}$ & $87.11 \pm 0.43^{\mathrm{b}}$ & $99.46 \pm 0.28^{\mathrm{a}}$ & $99.52 \pm 0.25^{\mathrm{a}}$ \\
\hline
\end{tabular}

Different lowercase letter in the same line indicates differences between samples subjected to different drying methods ( $\mathrm{P}<0.05)$; PSO: pumpkin seed oil; PSO1: cold-pressed PSO; PSO2: hot-pressed at $100^{\circ} \mathrm{C}$; PSO3: hot-pressed at $150^{\circ} \mathrm{C}$.

of this study indicated that polar bioactive compounds of the oil degraded and bioactive properties of oils significantly reduced with the application of heat treatment.

\subsection{In vitro cytotoxicity assay}

Pumpkin seeds provide many pharmacological effects and health benefits because of their excellent rich source of nutraceutical and pharmaceutical properties. Several in vitro, in vivo, and pre-clinical studies conducted in recent years have shown that pumpkin seeds oil has a wide range of extraordinary biological activities (Lestari \& Meiyanto, 2018). Pumpkin seed oil protects against some diseases due to its high contents of unsaturated fatty acids, sterols, and tocopherols (Patel, 2013).

In this study, the cytotoxic effect of pumpkin seed oil on Caco-2 adenocarcinoma cells was investigated and the cell viability $\%$ was given in Table 4, $30 \mathrm{mg} / \mathrm{mL}$ of PSO1, PSO2, and PSO3 samples exhibited a high cytotoxic effect on the cells with an inhibition ratio of $75 \%, 48 \%$, and $39 \%$, respectively (Figure 1).

While PSO2 and PSO3 were not effective significantly at concentrations below $10 \mathrm{mg} / \mathrm{mL}$, PSO1 has continued to inhibit at different levels due to its higher phenolic content. The fact that PSO1 contained a much higher amount of trans-cinnamic acid, benzoic acid, and protocatechuic acid compared to PSO2 and PSO3, increased its anticarcinogenic effect (Babich et al., 2002; Pontiki et al., 2014).

In similar research, Richter et al. examined the anticancer effect of pumpkin seed extracts on human breast cancer cells (MCF7) and human chorionic carcinoma cell lines (Jeg3 and BeWo) and found to be had a cytotoxic effect on those cells. In another in vitro study reported by Medjakovic et al. (2016), hydroalcoholic pumpkin seed extract inhibited cancer cell proliferation and hyperplastic cells. Moreover, in an animal study, the pumpkin seed oil inhibited testosterone-induced hyperplasia in rats which could provide management of benign prostatic hyperplasia (Gossell-Williams et al., 2006). In clinical trials conducted by Friederich et al. (2000) and Hong et al. (2009), pumpkin seed oil was included in a 3-months diet of benign prostate cancer $(\mathrm{BPH})$ patients and symptoms have been decreased, particularly in the early stage of cancer. In general, the anti-cancer molecular mechanism of pumpkin seeds should be further explained based on many types of cancer cells. 


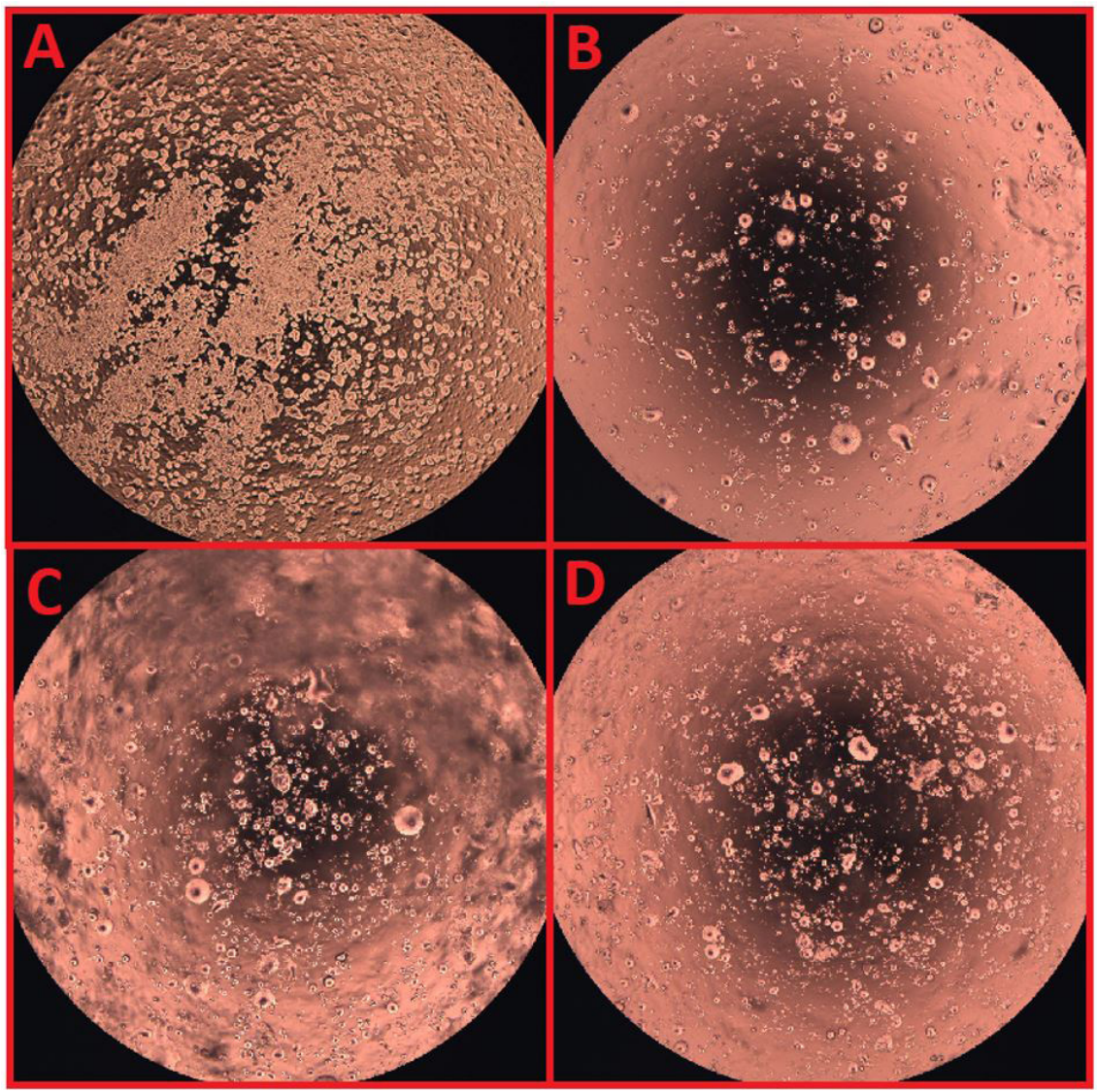

Figure 1. Inverted microscope images of Caco-2 cells treated with $30 \mathrm{mg} / \mathrm{mL}$ of PSO samples: (A) control cells (without PSO); (B) cells treated with PSO1; (C) cells treated with PSO2; and (D) cells treated with PSO3.

Table 5. The relative anti-inflammatory activity of PSO samples examined by protein denaturation assay.

\begin{tabular}{cccc}
\hline \multirow{2}{*}{ Sample amount $(\mu \mathrm{g} / \mathrm{mL})$} & \multicolumn{3}{c}{ Anti-inflammatory activity (\%) } \\
\cline { 2 - 4 } & PSO-1 & PSO-2 & PSO-3 \\
\hline 100 & $79.01 \pm 2.73^{\mathrm{a}}$ & $58.52 \pm 3.53^{\mathrm{c}}$ & $59.26 \pm 0.37^{\mathrm{b}}$ \\
50 & $71.73 \pm 1.50^{\mathrm{a}}$ & $55.19 \pm 1.11^{\mathrm{b}}$ & $54.57 \pm 2.52^{\mathrm{b}}$ \\
25 & $65.43 \pm 1.40^{\mathrm{a}}$ & $51.11 \pm 1.61^{\mathrm{b}}$ & $50.12 \pm 1.19^{\mathrm{b}}$ \\
\hline
\end{tabular}

Different lowercase letter in the same line indicates differences between samples subjected to different drying methods $(\mathrm{P}<0.05)$; PSO: pumpkin seed oil; PSO1: cold-pressed PSO; PSO2: hot-pressed at $100^{\circ} \mathrm{C}$; PSO3: hot-pressed at $150^{\circ} \mathrm{C}$.

\subsection{Anti-inflammatory activity}

Inflammation is commonly described as a complex biochemical reaction against harmful stimuli in vascular tissues. On the other hand, inflammation is related to pain and manifested by an increase in protein denaturation (Ferrero-Miliani et al., 2007). An anti-inflammatory agent is a substance used to decrease inflammation and discomfort (Bao et al., 2006). Pumpkin seeds have been traditionally used in the treatment of inflammation diseases in many countries (Ratnam et al., 2017). The antiinflammatory activity of PSO samples was given in Table 5 .

In protein denaturation assay, all the samples exhibited inhibition \% at different levels. PSO1 showed anti-inflammatory activity ranged from $79 \%$ to $59 \%$, while at the same concentrations $\mathrm{PSO} 2$ and $\mathrm{PSO} 3$ exhibited approximately from $58 \%$ to $49 \%$. The highest anti-inflammatory effect was observed at a concentration of $100 \mu \mathrm{g} / \mathrm{mL}$ of the PSO1 sample. It was considered to be due to the higher phenolic content of PSO1 compared to $\mathrm{PSO} 2$ and PSO3. On the other hand, there was no significant difference between the PSO2 and PSO3 samples. In a similar study conducted by Amin et al. (2020), the anti-inflammatory activity of indigenous and hybrid pumpkin seed oils was investigated and found that indigenous pumpkin seed oil had a higher effect with a rate of $89 \%$ at a concentration of $45 \mu \mathrm{g} / \mathrm{mL}$ compared to a hybrid one. In another in vivo study, the anti-inflammatory activity of pumpkin seed oils of an Egyptian and European variety was examined in a rat model of adjuvant arthritis and it was determined that PSO significantly reduced inflammation (Al-Okbi et al., 2017). Similarly, Arslanbas et al. (2020) examined the anti-inflammatory activity of Turkey source pumpkin seed oil in rat oedema model 
and observed that a significant anti-inflammatory effect in the group to which a high dosage of Turkey-sourced PSO $(100 \mathrm{mg} /$ $\mathrm{kg}$ ) was administered. As a result, PSO is a very effective agent to control inflammation and can be used in treatment of several chronic disease related with inflammation.

\section{Conclusion}

Cold press oils have become products that attract consumer attention due to their positive effects on health in recent years. During the cold press oil production, high temperature is not applied and the nutritional elements in the oil content are preserved. However, manufacturers change the composition of the oil by applying high temperatures to increase efficiency. In this study, the effect of heat application on the bioactive properties of oils produced by mechanical presses was investigated. The high press temperature caused a significant decrease in the amount of sterol, tocopherol, and phenolic compounds, reduction of cytotoxicity, and anti-inflammatory properties of the samples. The results of this study indicated that the high press temperature may cause significant changes in the bioactive properties of the oil and that the oils produced by applying high press temperatures could not meet the properties of the oils produced under cold press conditions.

\section{References}

Akcicek, A., \& Karasu, S. (2018). Utilization of cold pressed chia seed oil waste in a low-fat salad dressing as natural fat replacer. Journal of Food Process Engineering, 41(5), e12694. http://dx.doi.org/10.1111/ jfpe.12694.

Akin, G., Arslan, F. N., Karuk Elmasa, S. N., \& Yilmaz, I. (2018). Cold-pressed pumpkin seed (Cucurbita pepo L.) oils from the central Anatolia region of Turkey: characterization of phytosterols, squalene, tocols, phenolic acids, carotenoids and fatty acid bioactive compounds. Grasas y Aceites, 69(1), e232. http://dx.doi.org/10.3989/ gya.0668171.

Al-Okbi, S. Y., Mohamed, D. A., Kandil, E., Abo-Zeid, M. A., Mohammed, S. E., \& Ahmed, E. K. (2017). Anti-inflammatory activity of two varieties of pumpkin seed oil in an adjuvant arthritis model in rats. Grasas y Aceites, 68(1), e180. http://dx.doi.org/10.3989/gya.0796161.

Amin, M. Z., Rity, T. I., Uddin, M. R., Rahman, M. M., \& Uddin, M. J. (2020). A comparative assessment of anti-inflammatory, anti-oxidant and anti-bacterial activities of hybrid and indigenous varieties of pumpkin (Cucurbita maxima Linn.) seed oil. Biocatalysis and Agricultural Biotechnology, 28, 101767. http://dx.doi.org/10.1016/j. bcab.2020.101767.

Association on Official Analytical Chemists - AOAC. (2000). Official methods of analysis of AOAC. International 17th edition. Gaithersburg, MD, USA: Association of Analytical Communities.

Arslanbaş, E., Kara, H., Karayigit, O. M., Doğan, H., \& Yildiz, Ş. (2020). Anti-inflammatory activity of Turkey source pumpkin seed oil in rat oedema model. Acta Poloniae Pharmaceutica, Drug Research, 77, 305-312. http://dx.doi.org/10.32383/appdr/118962.

Association of Official Analytical Chemists - AOAC. (1990). Official methods of analysis of the Association of Official Analytical Chemists (15th ed., 1298 p.). Arlington: AOAC.

Babich, H., Sedletcaia, A., \& Kenigsberg, B. (2002). In vitro cytotoxicity of protocatechuic acid to cultured human cells from oral tissue: involvement in oxidative stress. Pharmacology \& Toxicology, 91(5),
245-253. http://dx.doi.org/10.1034/j.1600-0773.2002.910505.x. PMid:12570031.

Bao, F., John, S. M., Chen, Y., Mathison, R. D., \& Weaver, L. C. (2006). The tripeptide phenylalanine-(d) glutamate-(d) glycine modulates leukocyte infiltration and oxidative damage in rat injured spinal cord. Neuroscience, 140(3), 1011-1022. http://dx.doi.org/10.1016/j. neuroscience.2006.02.061. PMid:16581192.

Barriuso, B., Ansorena, D., Poyato, C., \& Astiasarán, I. (2015). Cholesterol and stigmasterol within a sunflower oil matrix: thermal degradation and oxysterols formation. Steroids, 99(Pt B), 155-160. http://dx.doi. org/10.1016/j.steroids.2015.02.009. PMid:25697057.

Begić, M., Nezirević-Nizić, E., Čorbo, S., Podrug, S., Asimovic, Z., \& Muminović, Š. (2020). Fatty acid composition and stability of coldpressed vegetable oils. In M. Brka, E. Omanović-Mikličanin, L. Karić, V. Falan \& A. Toroman (Eds.), 30th Scientific-Experts Conference of Agriculture and Food Industry. AgriConf 2019. IFMBE Proceedings (Vol. 78, pp. 303-312). Cham: Springer. https://doi.org/10.1007/9783-030-40049-1_39.

Benalia, M., Djeridane, A., Gourine, N., Nia, S., Ajandouz, E., \& Yousfi, M. (2015). Fatty acid profile, tocopherols content and antioxidant activity of algerian pumpkin seeds oil (Cucurbita pepo L). Mediterranean Journal of Nutrition and Metabolism, 8(1), 9-25. http://dx.doi.org/10.3233/MNM-140023.

Bruscatto, M., Pestana-Bauer, V., Otero, D., \& Zambiazi, R. (2019). Effects of heating temperature on the tocopherol contents of chemically and physically refined rice bran oil. Grasas y Aceites, 70(1), 294. http:// dx.doi.org/10.3989/gya.0572181.

Çakır Koç, R., Budama-Kilinc, Y., Kaya, Z., Orcen, B.B. , \& Uçarkuş, E. (2018). Coconut Oil-Loaded Chitosan Nanoparticles For The Treatment Of Acne Vulgaris: Cytotoxicity, Antibacterial Activity, And Antibiofilm Properties. Fresenius Environmental Bulletin, 27, 2642-2648.

Chen, J., Li, D., Tang, G., Zhou, J., Liu, W., \& Bi, Y. (2020). Thermaloxidation stability of soybean germ phytosterols in different lipid matrixes. Molecules (Basel, Switzerland), 25(18), 4079. http://dx.doi. org/10.3390/molecules25184079. PMid:32906624.

Dyshlyuk, L., Babich, O., Prosekov, A., Ivanova, S., Pavsky, V., \& Yang, Y. (2017). In vivo study of medical and biological properties of functional bakery products with the addition of pumpkin flour. Bioactive Carbohydrates and Dietary Fibre, 12, 20-24. http://dx.doi. org/10.1016/j.bcdf.2017.09.001.

Ferrero-Miliani, L., Nielsen, O. H., Andersen, P. S., \& Girardin, S. E. (2007). Chronic inflammation: Importance of NOD2 and NALP3 in interleukin- $1 \beta$ generation. Clinical and Experimental Immunology, 147(2), 227-235. http://dx.doi.org/10.1111/j.1365-2249.2006.03261.x. PMid:17223962.

Friederich, M., Theurer, C., \& Schiebel-Schlosser, G. (2000). Prosta Fink Forte $^{\circledast}$ in the therapy of benign prostatic hyperplasia. Multicentric surveillance study in 2,245 patients. Forschende Komplementärmedizin und klassische Naturheilkunde = Research in complementary and natural classical medicine, 7(4), 200-204. http://dx.doi.org/10.1159/000021344.

González-Larena, M., García-Llatas, G., Vidal, M. C., Sánchez-Siles, L. M., Barberá, R., \& Lagarda, M. J. (2011). Stability of Plant Sterols in Ingredients Used in Functional Foods. Journal of Agricultural and Food Chemistry, 59(8), 3624-3631. http://dx.doi.org/10.1021/ jf1044102. PMid:21395311.

Gossell-Williams, M., Davis, A., \& O’Connor, N. (2006). Inhibition of Testosterone-Induced Hyperplasia of the Prostate of SpragueDawley Rats by Pumpkin Seed Oil. Journal of Medicinal Food, 9(2), 284-286. http://dx.doi.org/10.1089/jmf.2006.9.284. PMid:16822218. 
Hong, H., Kim, C.-S., \& Maeng, S. (2009). Effects of pumpkin seed oil and saw palmetto oil in Korean men with symptomatic benign prostatic hyperplasia. Nutrition Research and Practice, 3(4), 323327. http://dx.doi.org/10.4162/nrp.2009.3.4.323. PMid:20098586.

Hung, H. C., Joshipura, K. J., Jiang, R., Hu, F. B., Hunter, D., SmithWarner, S. A., Colditz, G. A., Rosner, B., Spiegelman, D., \& Willett, W. C. (2004). Fruit and vegetable intake and risk of major chronic disease. Journal of the National Cancer Institute, 96(21), 1577-1584. http://dx.doi.org/10.1093/jnci/djh296. PMid:15523086.

International Union of Pure and Applied Chemistry - IUPAC. (1992). Standard methods for the analysis of oils, fats and derivatives. In C. Paquot \& A. Hautfenne (Eds.), International union of pure and applied chemistry (7th ed.). Oxford, UK: Blackwell Scientific Publications Inc.

Jurgita, K., Jariene, E., Danilcenko, H., Kita, A., \& Venskutoniene, E. (2007). Oil pumpkins seeds and their quality. Polish Journal of Food and Nutrition Sciences, 57, 349-352.

Kamm, W., Dionisi, F., Fay, L.-B., Hischenhuber, C., Schmarr, H.G., \& Engel, K.-H. (2002). Rapid and simultaneous analysis of 16-O-methylcafestol and sterols as markers for assessment of green coffee bean authenticity by on-line LC-GC. Journal of the American Oil Chemists'Society, 79(11), 1109-1113. http://dx.doi.org/10.1007/ s11746-002-0612-5.

Karasu, S., Kilicli, M., Baslar, M., Arici, M., Sagdic, O., \& Karaagacli, M. (2015). Dehydration kinetics and changes of bioactive compounds of tulip and poppy petals as a natural colorant under vacuum and oven conditions. Journal of Food Processing and Preservation, 39(6), 2096-2106. http://dx.doi.org/10.1111/jfpp.12453.

Kemmo, S., Ollilainen, V., Lampi, A.-M., \& Piironen, V. (2008). Liquid chromatography mass spectrometry for plant sterol oxide determination in complex mixtures. European Food Research and Technology, 226(6), 1325-1334. http://dx.doi.org/10.1007/s00217-007-0661-5.

Lestari, B., \& Meiyanto, E. (2018). A review: the emerging nutraceutical potential of pumpkin seeds. Indonesian Journal of Cancer Chemoprevention, 9(2), 92. http://dx.doi.org/10.14499/ indonesianjcanchemoprev9iss2pp92-101.

Lin, Y., Knol, D., Valk, I., van Andel, V., Friedrichs, S., Lütjohann, D., Hrncirik, K., \& Trautwein, E. A. (2017). Thermal stability of plant sterols and formation of their oxidation products in vegetable oils and margarines upon controlled heating. Chemistry and Physics of Lipids, 207(Pt B), 99-107. http://dx.doi.org/10.1016/j. chemphyslip.2017.01.007. PMid:28163064.

Medjakovic, S., Hobiger, S., Ardjomand-Woelkart, K., Bucar, F., \& Jungbauer, A. (2016). Pumpkin seed extract: Cell growth inhibition of hyperplastic and cancer cells, independent of steroid hormone receptors. Fitoterapia, 110, 150-156. http://dx.doi.org/10.1016/j. fitote.2016.03.010. PMid:26976217.

Montesano, D., Blasi, F., Simonetti, M., Santini, A., \& Cossignani, L. (2018). Chemical and Nutritional Characterization of Seed Oil from Cucurbita maxima L. (var. Berrettina) Pumpkin. Foods, 7(3), 30. http://dx.doi.org/10.3390/foods7030030. PMid:29494522.

Murkovic, M., Piironen, V., Lampi, A. M., Kraushofer, T., \& Sontag, G. (2004). Changes in chemical composition of pumpkin seeds during the roasting process for production of pumpkin seed oil (Part 1: non-volatile compounds). Food Chemistry, 84(3), 359-365. http:// dx.doi.org/10.1016/S0308-8146(03)00240-1.

Nawirska-Olszańska, A., Kita, A., Biesiada, A., Sokół-Łętowska, A., \& Kucharska, A. (2013). Characteristics of antioxidant activity and composition of pumpkin seed oils in 12 cultivars. Food Chemistry, 139(1-4), 155-161. http://dx.doi.org/10.1016/j.foodchem.2013.02.009. PMid:23561092.
Neđeral, S., Škevin, D., Kraljić, K., Obranovic, M., Papeša, S., \& Bataljaku, A. (2012). Chemical composition and oxidative stability of roasted and cold pressed pumpkin seed oils. Journal of the American Oil Chemists' Society, 89(9), 1763-1770. http://dx.doi.org/10.1007/ s11746-012-2076-0.

O'Callaghan, Y., McCarthy, F. O., \& O'Brien, N. M. (2014). Recent advances in phytosterol oxidation products. Biochemical and Biophysical Research Communications, 446(3), 786-791. http://dx.doi. org/10.1016/j.bbrc.2014.01.148. PMid:24491535.

Ogrodowska, D., Tanska, M., \& Brandt, W. (2017). The influence of drying process conditions on the physical properties, bioactive compounds and stability of encapsulated pumpkin seed oil. Food and Bioprocess Technology, 10(7), 1265-1280. http://dx.doi.org/10.1007/ s11947-017-1898-z.

Parry, J. W., Cheng, Z., Moore, J., \& Yu, L. L. (2008). Fatty acid composition, antioxidant properties, and antiproliferative capacity of selected cold-pressed seed flours. Journal of the American Oil Chemists' Society, 85(5), 457-464. http://dx.doi.org/10.1007/s11746-008-1207-0.

Patel, S. (2013). Pumpkin (Cucurbita sp.) seeds as nutraceutic: a review on status quo and scopes. Mediterranean Journal of Nutrition and Metabolism, 6(3), 183-189. http://dx.doi.org/10.3233/s12349-0130131-5.

Pontiki, E., Hadjipavlou-Litina, D., Litinas, K., \& Geromichalos, G. (2014). Novel cinnamic acid derivatives as antioxidant and anticancer agents: design, synthesis and modeling studies. Molecules (Basel, Switzerland), 19(7), 9655-9674. http://dx.doi.org/10.3390/ molecules19079655. PMid:25004073.

Potočnik, T., Rak Cizej, M., \& Košir, I. J. (2018). Influence of seed roasting on pumpkin seed oil tocopherols, phenolics and antiradical activity. Journal of Food Composition and Analysis, 69, 7-12. http:// dx.doi.org/10.1016/j.jfca.2018.01.020.

Rabrenović, B. B., Dimić, E. B., Novaković, M. M., Tešević, V. V., \& Basić, Z. N. (2014). The most important bioactive components of cold pressed oil from different pumpkin (Cucurbita pepo L.) seeds. Lebensmittel-Wissenschaft + Technologie, 55(2), 521-527. http:// dx.doi.org/10.1016/j.lwt.2013.10.019.

Rabrenovic, B. B., Vujasinovic, V. B., Novakovic, M. M., Corbo, S. C., \& Basic, Z. N. (2016). Comparative Review of the nutritional value of cold-pressed pumpkin (Cucurbita Pepo L.) seed oil of different origins. Hemijska Industrija, 70(1), 59-65. http://dx.doi.org/10.2298/ HEMIND141128011R.

Raczyk, M., Siger, A., Radziejewska-Kubzdela, E., Ratusz, K., \& Rudzińska, M. (2017). Roasting pumpkin seeds and changes in the composition and oxidative stability of cold-pressed oils. Acta Scientiarum Polonorum. Technologia Alimentaria, 16(3), 293-301. http://dx.doi.org/10.17306/J.AFS.0494. PMid:29055977.

Ratnam, N., Vandana, Najibullah, M., \& Ibrahim, M. (2017). A review on Cucurbita pepo. International Journal of Pharmacognosy and Phytochemical Research, 9(9), 1190-1194. https://doi.org/10.25258/ phyto.v9i09.10305.

Sakat, S., Juvekar, A.R., \& Gambhire, M.N. (2010). In vitro antioxidant and anti-inflammatory activity of methanol extract of Oxalis corniculata Linn. International Journal of Pharmacy and Pharmaceutical Sciences, 2(1), 146-155.

Sarungallo, Z. L., Hariyadi, P., Andarwulan, A., \& Purnomo, E. H. (2020). Effect of heat treatment prior to extraction on the yield and quality of red fruit (Pandanus conoideus) oil. Food Research, 4(3), 659-665. http://dx.doi.org/10.26656/fr.2017.4(3).281.

Siegmund, B., \& Murkovic, M. (2004). Changes in chemical composition of pumpkin seeds during the roasting process for production of 
pumpkin seed oil (Part 2: volatile compounds). Food Chemistry, 84(3), 367-374. http://dx.doi.org/10.1016/S0308-8146(03)00241-3.

Singh, R. P., Chidambara Murthy, K. N., \& Jayaprakasha, G. K. (2002). Studies on the antioxidant activity of pomegranate (Punica granatum) peel and seed extracts using in vitro models. Journal of Agricultural and Food Chemistry, 50(1), 81-86. http://dx.doi.org/10.1021/ jf010865b. PMid:11754547.

Singleton, V. L., \& Rossi, J. A. (1965). Colorimetry of total phenolics with phosphomolybdic-phosphotungstic acid reagents. American Journal of Enology and Viticulture, 16(3), 144-158. Retrieved from https://www.ajevonline.org/content/ajev/16/3/144.full.pdf

Stevenson, D. G., Eller, F. J., Wang, L., Jane, J.-L., Wang, T., \& Inglett, G. E. (2007). Oil and tocopherol content and composition of pumpkin seed oil in 12 cultivars. Journal of Agricultural and Food Chemistry, 55(10), 4005-4013. http://dx.doi.org/10.1021/jf0706979. PMid:17439238.

Tadmor, Y., Paris, H., Meir, A., Schaffer, A., \& Lewinsohn, E. (2005). Dual role of the pigmentation gene $\mathrm{b}$ in affecting carotenoid and vitamin E content in squash (Cucurbita pepo) mesocarp. Journal of
Agricultural and Food Chemistry, 53(25), 9759-9763. http://dx.doi. org/10.1021/jf0520591. PMid:16332127.

Tekin, Z. H., \& Karasu, S. (2020). Cold-pressed flaxseed oil by-product as a new source of fat replacers in low-fat salad dressing formulation: steady, dynamic and 3-ITT rheological properties. Journal of Food Processing and Preservation, 44(9), e14650. http://dx.doi.org/10.1111/ jfpp.14650.

Tekin-Cakmak, Z. H., Karasu, S., Kayacan-Cakmakoglu, S., \& Akman, P. K. (2021). Investigation of potential use of by-products from coldpress industry as natural fat replacers and functional ingredients in a low-fat salad dressing. Journal of Food Processing and Preservation, 45(8), e15388.

Vujasinovic, V., Djilas, S., Dimic, E., Basic, Z., \& Radocaj, O. (2012). The effect of roasting on the chemical composition and oxidative stability of pumpkin oil. European Journal of Lipid Science and Technology, 114(5), 568-574. http://dx.doi.org/10.1002/ejlt.201100158.

Wan, H., Liu, R., Sun, H., Yu, X., Li, Y., Cong, Y., \& Liu, D. (2014). Caco- 2 cell-based antioxidant activity of 36 vegetables commonly consumed in China. Journal of Food and Nutrition Research, 2(2), 88-95. http://dx.doi.org/10.12691/jfnr-2-2-5. 